\title{
Studies on Cholinesterase
}

\section{A METHOD FOR THE PURIFICATION OF A PSEUDO-CHOLINESTERASE FROM DOG PANCREAS}

\author{
By B. MENDEL AND D. B. MUNDELL, The Banting and Best Department of Medical \\ Research, Banting Institute, University of Toronto, Canada
}

(Received 8 October 1942)

Many papers have been published on the properties and distribution of cholinesterase in the animal body but few attempts have been made at its purification. Stedman \& Stedman [1935] purified the enzyme from horse serum 50 to 100 times; McMeekin [1939], using a different method, slightly increased the degree of purity. In this laboratory preparations about 20 times as active as Stedman's were procured from horse serum, but the yield was very low and the method not suitable for operations on a larger scale.

The only previous attempt to purify cholinesterase from tissues was made by Nachmansohn \& Lederer [1939], who obtained aqueous extracts from the electric organ of the Torpedo vulgaris which were about three times as active as Stedman's purest preparations.

For the purification of tissue cholinesterase, to be described in this paper, dog pancreas was chosen, as it was known to contain large amounts of the enzyme [Marnay, 1938]. The pancreas of larger animals such as horse, ox and hog were tested for cholinesterase activity, but were so much less active than dog pancreas that purification was not attempted.

The method of purification is relatively simple. Only two chemicals, $\left(\mathrm{NH}_{4}\right)_{2} \mathrm{SO}_{4}$ and kieselguhr, are used in the process, which consists of four main steps: (1) extraction of the enzyme with water; (2) fractionation with $\left(\mathrm{NH}_{4}\right)_{2} \mathrm{SO}_{4} ;(3)$ adsorption on to kieselguhr, and (4) elution with ammonium sulphate.

The final preparation, $1 \mathrm{mg}$. of which hydrolyses about $1.2 \mathrm{mg}$. of acetylcholine per sec., is approximately 2000 times as active per unit dry weight as its source and 100-200 times as active as the purest preparations described by McMeekin or Stedman.

The purified enzyme proved to be a pseudocholinesterase [Mendel \& Rudney, 1943], since it attacked a variety of non-choline esters and hydrolysed acetylcholine with maximum speed at a comparatively high substrate concentration (about $0.02 M)$.

\section{EXPERIMENTAL}

\section{Estimation of cholinesterase activity}

The activity of the enzyme is measured manometrically by the Warburg method, first adopted for the measurement of cholinesterase activity by
Ammon [1933]. An aqueous solution of the enzyme preparation $(0.1 \mathrm{ml}$. or less) is placed in the main compartment of a Warburg flask and brought to a volume of $1.9 \mathrm{ml}$. with a solution of $0.025 \mathrm{M}$ $\mathrm{NaHCO}_{3}$, previously saturated with $5 \% \mathrm{CO}_{2}$ in $\mathrm{N}_{2}$. The flask is attached to the manometer and filled with the above-mentioned gas mixture, in order to maintain the enzyme solution at a constant $p H$ (7·4). $0.1 \mathrm{ml}$. of a $10 \%$ aqueous solution of acetylcholine chloride (Hoffmann la Roche) is tipped from the side bulb into the main compartment after temperature equilibrium at $37 \cdot 5^{\circ}$ has been attained.

$1 \mathrm{~m}$.-mol. of acetylcholine, when hydrolysed by the enzyme into choline and acetic acid, evolves $1 \mathrm{~m}$.-mol. of $\mathrm{CO}_{2}$ from the $\mathrm{NaHCO}_{3}$. The amount of $\mathrm{CO}_{2}$ in $\mu \mathrm{l}$. evolved in $1 \mathrm{hr}$. by $1 \mathrm{mg}$. dry weight of the enzyme preparation, is referred to as the acetylcholine quotient $\left(Q_{\mathrm{ACh}}\right)$.

\section{METHOD OF PURIFICATION}

\section{Extraction}

The pancreas is removed from 4 or 5 dogs immediately after electrocution, rinsed with cold water, and freed from fat, mesentery and visible blood vessels. The tissue, weighing about $100 \mathrm{~g}$., is cut into small pieces, finely minced (an electric mixer, 'Whizmix', was found very efficient for mincing and mixing the tissue with water) and extracted with 9 parts of cold distilled water. Extraction is allowed to continue for at least 5, but not longer than $20 \mathrm{hr}$., in the refrigerator (about $+2^{\circ}$ ); the mixture is then strained through a coarse sieve (18 mesh) to remove fibrous tissue. The $Q_{\mathrm{ACh}}$ of the strained suspension varies from 200 to 400 , the higher values generally being obtained during July, August and September.

\section{Fractionation with ammonium sulphate}

A. Precipitation at 0.48 saturation. The strained suspension is gradually brought to 0.48 saturation with an $\left(\mathrm{NH}_{4}\right)_{2} \mathrm{SO}_{4}$ solution (sat. at $20^{\circ}$ ) by adding $2 / 3$ of the required $\left(\mathrm{NH}_{4}\right)_{2} \mathrm{SO}_{4}$ at once and the remainder $2 \mathrm{hr}$. later: this prevents any of the albumin fraction from being carried down prematurely with the bulky precipitate. Throughout this procedure, and for 3 or $4 \mathrm{hr}$. afterwards-the time required for 
complete flocculation-the mixture is allowed to stand in the refrigerator. At this stage of purity the enzyme preparation can be kept in the cold for weeks without loss of activity.

The flocculent suspension is then centrifuged in a high speed centrifuge (a Sharples Super Centrifuge run by air pressure) and the precipitate is discarded.* The active $(0.48$ sat.) fluid is brought to 0.85 sat. with solid $\left(\mathrm{NH}_{4}\right)_{2} \mathrm{SO}_{4}$ in order to concentrate the enzyme by precipitation. The mixture, having been kept in the cold for at least $3 \mathrm{hr}$., is repeatedly filtered through filter paper on a Büchner funnel by suction, until the filtrate is clear.

The active filter cake is scraped from the filter paper and thoroughly mixed with a quantity of water equal to $1 / 20-1 / 10$ of the original volume of the extract. The mixture is centrifuged to eliminate coarse insoluble material; a floating layer of fat, which may have formed, is removed as completely as possible. The turbid supernatant fluid is then dialysed in cellophane bags against running tap water (below $15^{\circ}$ ) for at least 16 but not longer than $20 \mathrm{hr}$. An inactive precipitate which forms during dialysis is removed by centrifuging.

The dialysed enzyme solution is again brought to 0.85 sat. with solid $\left(\mathrm{NH}_{4}\right)_{2} \mathrm{SO}_{4}$ and filtered as described above. The filter cake is dissolved in the smallest possible amount of water and dialysed against running tap water for $20 \mathrm{hr}$. After dialysis any precipitate is centrifuged off and the brownish coloured enzyme solution is dried in vacuo over $\mathrm{CaCl}_{2}$ at a temperature not exceeding $+2^{\circ}$. At this stage the $Q_{\mathrm{ACh}}$ ranges from 8000 to 12,000 . Since the dried active material is stable when kept on ice, it can conveniently be collected and stored at this point.

When a sufficient quantity of the dried preparation (3-4 g.) has been accumulated, it is dissolved in about 10 parts of cold distilled water. Much insoluble inactive material is removed by centrifuging, and the enzyme solution is dialysed in the refrigerator for $36 \mathrm{hr}$. against frequently changed distilled water. After dialysis the $Q_{\mathrm{ACh}}$ is about 20,000 .

B. Precipitation at 0.5 saturation. An equal volume of sat. $\left(\mathrm{NH}_{4}\right)_{2} \mathrm{SO}_{4}$ is added to the dialysed enzyme preparation, and the mixture is kept in the refrigerator for about $1 \mathrm{hr}$. The resulting flocculent precipitate is inactive and should be removed by centrifuging.

C. Precipitation at 0.52 saturation. By addition of more saturated $\left(\mathrm{NH}_{4}\right)_{2} \mathrm{SO}_{4}$ solution, the active 0.5 sat. fluid is brought to exactly 0.52 sat. and is then kept at $37^{\circ}$ for $15 \mathrm{~min}$. An inactive precipitate

\footnotetext{
* The esterase is associated with both the globulin and albumin fractions of the pancreas proteins, but since it was found very difficult to purify the globulin part, only the albumin fraction (containing about $1 / 2$ of the esterase activity) was used for further purification.
}

forms and is removed by centrifuging. The active fluid is again concentrated by precipitation with solid $\left(\mathrm{NH}_{4}\right)_{2} \mathrm{SO}_{4}(0.85$ sat.) and is filtered as before. The filter cake is dissolved in as small a volume of water as possible and dialysed against running water (below $15^{\circ}$ ) for $20 \mathrm{hr}$. At this stage the preparation has a $Q_{\mathrm{ACh}}$ of approximately 40,000 . It may be dried in vacuo at a temperature not exceeding $2^{\circ}$ and stored in the cold for about 2 months without loss of activity.

\section{Adsorption on to kieselguhr}

When at least $0.5 \mathrm{~g}$. of the dried enzyme material with a $Q_{\mathrm{ACh}}$ of about 40,000 has been accumulated, it is dissolved in about 20 parts of cold water and dialysed against frequently changed distilled water in the refrigerator for $36 \mathrm{hr}$. After dialysis, the brownish coloured liquid is shaken for $10 \mathrm{~min}$. with the least amount of kieselguhr* which will adsorb about $95 \%$ of the active material. The kieselguhr suspension is cooled in ice-water and centrifuged for a few minutes. The supernatant liquid, containing the greater part of the brownish coloured inactive material, is discarded. The kieselguhr is washed with cold distilled water and then centrifuged; this is repeated several times until the water has become colourless. Very little active material is lost in the course of this procedure.

\section{Elution}

A cold $0 \cdot 1$ sat. $\left(\mathrm{NH}_{4}\right)_{2} \mathrm{SO}_{4}$ solution, equal in volume to the enzyme solution before adsorption, is added to the kieselguhr. The suspension, while being cooled in ice-water, is stirred mechanically by a glass rod for 10-15 min. It is then centrifuged for a very short time. The resulting supernatant liquid contains 40 $60 \%$ of the adsorbed active material and the yield can be increased to about $75 \%$ by a second elution.

The combined clear eluates are brought to 0.85 sat. with solid $\left(\mathrm{NH}_{4}\right)_{2} \mathrm{SO}_{4}$ and are kept in the cold for at least $6 \mathrm{hr}$. A flocculent precipitate forms and the suspension is filtered repeatedly through filter paper on a small Büchner funnel (diameter ca. $2 \mathrm{~cm}$.) by suction until the filtrate is perfectly clear and the filter cake almost dry. The filter paper with the adhering layer of precipitate is placed in a small beaker containing not more than $5 \mathrm{ml}$. of ice-cold distilled water. Unless a fairly concentrated solution of the enzyme material is prepared, considerable loss of activity may occur during dialysis. The active material, which dissolves readily, is transferred to a cooled centrifuge tube, and the liquid absorbed by the filter paper is squeezed out and added. The

* About 3 g. of kieselguhr 'Brocades-Stheeman (Amsterdam)' are required for $50 \mathrm{ml}$. of the enzyme solution. Other brands of kieselguhr, such as B.D.H. kieselguhr, white, are suitable but not quite as efficient. 
solution, having been cooled, is centrifuged for 2 or $3 \mathrm{~min}$. to remove any traces of filter paper, and should then be dialysed for 2 days in the refrigerator against frequently changed distilled water. An inactive precipitate may form which can be eliminated by centrifuging. The enzyme solution is now colourless and has a $Q_{A C h}$ of $400,000-600,000$.

The yield of this purified preparation amounts to about $20 \%$ of the original activity of the pancreas, but is much greater ( $40 \%)$ when calculated on the basis that only the albumin fraction is used for purification.

Since enzyme preparations with a $Q_{\text {Ach }}$ above 10,000 are adversely affected by salts and dilution with water,* they should be diluted, and their activity measured, in a solution of $0.25 \%$ gum acacia.

* Effects of salts and dilution with water will be discussed in a subsequent paper dealing with the properties of the purified enzyme.

\section{SUMMARY}

A simple method is described by which a tissue esterase, capable of hydrolysing acetylcholine, may be purified from dog pancreas. The final preparation, $1 \mathrm{mg}$. of which hydrolyses about $70 \mathrm{mg}$. of acetylcholine per minute, is 2000 times as active per unit dry weight as the original material and about 15,000 times as active as horse serum.

The enzyme is a pseudo-cholinesterase, since it hydrolyses esters other than those of choline, and splits acetylcholine with maximum speed at a substrate concentration $(0.02 M)$ far above physiological range.

Grateful acknowledgement is made to the Banting Research Foundation for a personal grant to one of the authors (D. B. M.) and to Mr H. Rudney for valuable assistance in obtaining and preparing the pancreas tissue.

\title{
REFERENCES
}

Ammon, R. [1933]. Pflüg. Arch. ges. Physiol. 233, 486. Marnay, A. [1938]. C.R. Soc. Biol., Paris, 128, 519. McMeekin, T. L. [1939]. J. biol. Chem. 128, Proc. Ixvi. Mendel, B. \& Rudney, H. [1943]. Biochem. J. 37, 59.
Nachmansohn, D. \& Lederer, E. [1939]. Bull. Soc. Chim. biol., Paris, 21, 797.

Stedman, E. \& Stedman, E. [1935]. Biochem. J. 29, 2563.

\section{Methods for the Purification of Tomato Bushy Stunt and Tobacco Mosaic Viruses}

\author{
By F. C. BAWDEN AND N. W. PIRIE, Rothamsted Experimental Station, Harpenden, Herts
}

(Received 4 September 1942)

Since we first described methods for making liquid crystalline preparations of tobacco mosaic virus [Bawden \& Pirie, 1937] and crystalline preparations of tomato bushy stunt virus [Bawden \& Pirie, 1938], we have made preparations of both viruses by many other methods. As a result, we can now describe simpler and better procedures. Other workers have used differential ultracentrifugation; because of the infrequency with which stable substances of high molecular weight seem to occur in normal leaves, this method of preparation is undoubtedly of great value. The handling of large volumes of sap in the ultracentrifuge, however, is laborious, and many laboratories where plant viruses are studied do not have this equipment. Methods of preparation that are trustworthy and involve only ordinary centrifuges may therefore be of more general use.

\section{Tomato bushy stunt virus}

In our earlier method the sap was heated to $60^{\circ}$ to coagulate the normal leaf protein, and if the preparation is needed solely for a study of its serological or physical properties this is still probably the simplest procedure. However, heating to this extent greatly reduces the infectivity of the virus [Smith, 1935; Stanley, 1940], apparently without affecting its other properties appreciably, and more infective preparations can be made in other ways. The method described below is the most satisfactory we have found, but with small quantities of sap, precipitation with alcohol, as used by Pirie, Smith, Spooner \& McClement [1938] for tobacco necrosis viruses, is also suitable and quicker.

Preparation. Leaves and stems of infected tomato plants are put through a domestic meat mincer with ${ }_{1 \%}^{3}$ in. holes in the plate, and sap is expressed from the mince by hand through a bag of thin, closely woven cloth such as madapollam. For each $100 \mathrm{ml}$. of sap expressed, $30 \mathrm{ml}$. of a $4 \%$ solution of anhyd. $\mathrm{Na}_{2} \mathrm{HPO}_{4}$ is added to the residue in the bag; when this has soaked in, the residue is again put through the mincer and the sap is expressed as before. The two extracts are mixed, centrifuged and the precipitate discarded. The supernatant fluid is usually clear and brown, 